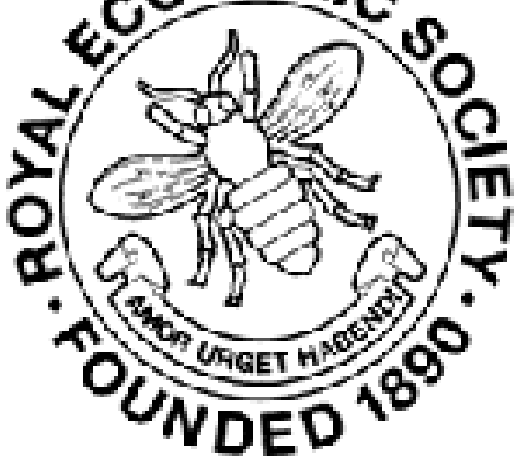

The Ausgleich Between Austria and Hungary

Author(s): A. Matlekovits

Source: The Economic Journal, Vol. 8, No. 29 (Mar., 1898), pp. 17-27

Published by: Wiley on behalf of the Royal Economic Society

Stable URL: http://www.jstor.org/stable/2956694

Accessed: 27-06-2016 02:46 UTC

Your use of the JSTOR archive indicates your acceptance of the Terms \& Conditions of Use, available at

http://about.jstor.org/terms

JSTOR is a not-for-profit service that helps scholars, researchers, and students discover, use, and build upon a wide range of content in a trusted digital archive. We use information technology and tools to increase productivity and facilitate new forms of scholarship. For more information about JSTOR, please contact support@jstor.org.

Royal Economic Society, Wiley are collaborating with JSTOR to digitize, preserve and extend access to The Economic Journal 


\section{THE AUSGLEICH BETWEEN AUSTRIA AND HUNGARY}

[THE recent discussions on the financial relations between Great Britain and Ireland lend especial interest to the following account of the financial and commercial relations between Austria and Hungary-the so-called Ausgleich---which we have received from our Hungarian correspondent, His Excellency Alexander Matlekovits, formerly Secretary of State.

In our next number we shall publish an article upon the new income-tax in Austria.-EDD. E. J.]

After the disastrous termination of the rising in 1848-9 Austria abolished the ancient Constitution of Hungary and reduced the kingdom to the level of a simple Austrian province, with the same political, financial, and administrative system then in use in the Austrian provinces. The passive resistance of the Hungarian nation, as also the fatal consequences of the Italian campaign in the year 1859, and still more those of the disastrous Prussian campaign in the year 1866, convinced the statesmen in Vienna that it was not possible to govern Hungary despotically. After prolonged negotiations political agreement was arrived at in 1867. This achievement is the work of Francis Deak. The agreement is based upon the re-establishment of the ancient Constitution in Hungary, with an independent Ministry, in accordance with the law of 1848, Austria being governed by a constitutional Government, and the common affairs of the two independent States forming the monarchy being arranged in accordance with the Pragmatic Sanction, by which all the States under the rule of the reigning House of Hapsburg are joined together for the purpose of common defence.

The common affairs referred to in this agreement are-the army and navy, foreign affairs, and financial affairs connected with them. Thus it is that there exist, besides the separate

No. 29.-VoL. VIII 
Hungarian Ministry and the separate Austrian Ministry, three Ministers who are at the same time Austrian and Hungarian functionaries, the Minister of War, the Minister for Foreign Affairs, and the Minister for Common Finance. These common Ministers are not responsible to either the Hungarian or Austrian Parliament, but to the Delegations, which are annually elected by the two Parliaments. The Delegations, that is, the Austrian Delegation and the Hungarian Delegation, sit and deliberate separately, and only in case the two bodies should not vote identical resolutions have they to meet together in equal numbers as one body to divide on the question in dispute, no debate or amendment being allowed. The Budget and financial statement and balance relating to common affairs are laid before the Delegations. The common Ministers are responsible to the Delegations, who vote the common Budget and pass the accounts of expenditure. With this their functions are exhausted. They have no legislative power, there being no laws common to both States. Every matter that requires legislation is brought before the Hungarian Parliament by the Hungarian Minister, or before the Austrian Parliament by the Austrian Minister, and thus is treated separately as Hungarian and as Austrian law.

The agreement of 1867 also prescribes the manner in which the common expenditure is to be provided for. The proportion in which Hungary contributes to the common expenditure must be settled beforehand by mutual agreement. This proportion is known as the Quota. The Quota can only be fixed for a certain limited time, and the procedure is as follows: $(a)$ Each Parliament nominates a Commission, called the Regnicolar Commission, which prepares proposals based upon data furnished by responsible Ministers; if the two Regnicolar Commissions agree upon the proposals such proposals are laid before their respective Legislatures, and, if accepted, become law; (b) If the Regnicolar Commissions should be unable to agree, their report is laid before the Legislature, which decides the question. In this case the Government proposals are put forward for debate; (c) If the two. Parliaments should be unable to agree, it is enacted that the Sovereign shall decide the question but such decision holds good, according to the Austrian law, only for one year.

In 1867 the question of the Austrian State Debt and the part of it that burdens Hungary was likewise settled. It was stated that such part of the Austrian Public Debt as was incurred without the sanction of the Hungarian Parliament could not be considered legally binding on Hungary, but that, in fairness, 
Hungary should acknowledge a certain part of the State Debt, and should contribute annually 29,188,000 florins towards interest, and 1,500,000 florins to the Sinking Fund. The Floating Debt of 312 million florins, consisting of currency in State notes and small coins, was to be guaranteed jointly by both Governments. Since then the Austrian, as well as the Hungarian, State Debt have been kept absolutely separate.

The agreement of 1867 treats also of certain matters-besides the common affairs and the State Debt-which might, for one reason or another, be more advantageously managed by mutual consent. But with regard to commercial relations it was stipulated that treaties, periodically renewable, should be concluded by the two Governments and sanctioned by the respective Legislatures. At that time a Commercial and Customs Alliance was concluded for ten years, the main points of which were: (a) Austria and Hungary form one Customs territory, their Customs Tariff and policy to be settled by mutual agreementthe income from Customs to go into the common Exchequer. The Custom Houses on Hungarian territory to be managed by Hungarian civil servants, and those on Austrian territory by Austrians; (b) The Salt and Tobacco monopoly, the brandy, sugar, and beer duties to be managed according to the same rules and regulations, drawbacks to be paid out of the Customs revenue; (c) The Currency (Valuta) to remain the same for both countries, and only to be altered by mutual consent; $(d)$ For the Mercantile Marine one law and one flag; the management of the Post Office, Telegraphs, and Railways to be subject to identical rules and regulations.

All the above-mentioned economic questions were to be settled periodically. The agreement of 1867 ran for ten years. The negotiations for the next period began as early as the year 1876, but were only concluded in July of the year 1878, again for ten years. The third agreement, which terminates at the end of the year 1897, was concluded in the year 1887. The negotiations for the renewal of the agreement, commenced in 1896, have not yet resulted in any definitive conclusion.

It is proposed to describe here some phases of these agreements.

First, as regards the Quota, in 1867 the Government collected data for the purpose of determining it; these data related to the period 1860-1865, during which an absolutely uniform law of taxation was applied to all parts of the Monarchy, the Government being carried on by the central power in Vienna on 
absolutist principles. It was found that during the period 18601865 Austria had contributed $949 \cdot 75$ million florins, and Hungary 317.4 million florins towards the common expenditure, giving a proportion of 75 to 25 . The Austrian Quota Commission, however, declined to accept this basis for the Quota, and insisted on taking direct taxation as the basis. The amount of direct taxation for the six years being 395.1 million florins and 199.8 million florins respectively, a ratio of 66.5 to 33.5 was arrived at. The Hungarian Commission moved that indirect taxation should also be taken into account, which would have made the ratio 71 to 29. The Austrian Commission accepted the principle that total taxation should be taken as a basis, but they pointed out that there were several taxes which were not identical in both countries, such as the highway tolls, the hall-marking duties, the excise duties in towns with octrois, and the wine and beer duty, all of which they desired to be left out of the calculation, which then would have resulted in the relation of 69 to 31 . The Quota Commission finally settled the Quota by compromise on the basis of 70 to 30 .

This settlement remained in force till 1872 . In that year the so-called Frontier Districts, which up to that time stood under a purely Military Government, were enfranchised and placed under the regular Civil Government, being at the same time incorporated with the kingdom of Hungary. At that time it was agreed that Hungary should contribute, in respect of the Frontier Districts, 2 per cent. towards the expenses of common affairs, and that the rest should be treated on the accepted basis of 30 to 70 . Thus the proportion in which each country contributes towards the common expenditure was calculated in the following manner : (a) Hungary paid from every 100, 2 per cent. ; and $(b)$ from the remaining 98,30 per cent.; or Hungary paid 31.4 per cent., and Austria 68.6 per cent. This Quota was not altered by the subsequent agreements of 1878 and 1887. But it must be remembered that the Quota Commissions never came to a final agreement about the principle of calculation, but merely arrived at a compromise. In 1878 the compromise was. entered into by the two Governments, and not by the Commissions, which were totally unable to agree. In 1887 the compromise was effected by the Commissions themselves.

With regard to the settled proportion in which the common expenditure is provided for, it should be mentioned that the Customs Revenue is first of all applied to it, and that the remainder is made up by the two countries, in the proportion as 
set out. During the last few years the common expenditure amounted, on the average, to about 150 million florins, of which 50 millions were contributed by the Customs Revenue, leaving 100 millions to be provided for by the Quota, or 31.4 millions by Hungary and $68^{\circ} 6$ by Austria, that is, every per cent. of the Quota is equal to about one million florins.

In connection with the Quota other questions besides common affairs have acquired importance. In 1878 questions of drawbacks and banking gave rise to prolonged contests. By the agreement of 1867 it was settled that the excise on sugar, brandy and beer should be levied upon the manufacturer, and a drawback allowed on exportation. This drawback was to be paid out of the Customs Revenue, and as the Austrian breweries and sugar factories exported a great deal more than the Hungarian it was evident that the contributions made according to the Quota of 68 per cent. were unfavourable to Hungary. The drawbacks paid to Austrian breweries and sugar factories resulted in a surcharge of about $1 \frac{1}{2}$ to 2 million florins, which Hungary had to pay. It was therefore arranged in 1878 that each country should contribute to the payment of drawback in the proportion in which their respective amount of production stood; for instance, Hungary would contribute only 16.66 per cent., one-sixth of the whole drawbacks, if her sugar production amounted only to one-sixth of the total production.

In 1878 the Bank question also arose, the Privilege granted by Charter to the Austrian National Bank expiring in 1876. Hungary always contended that the Charter of the National Bank was, as far as she was concerned, of no legal effect. In 1867, in concluding the first agreement, the Hungarian Government merely gave a pledge not to alter the status quo of the Bank question, until the expiration of the Charter. During the crisis of 1869 and 1873 the Bank question assumed great importance, and there was a strong movement in Hungary for the establishment of a separate bank. During the negotiations in 1878 both parties recognised the fact that Hungary was entitled to create a bank of her own, but she was then willing to grant to the National Bank the Privilege of issuing notes in Hungary if the title were changed from "National Bank" to that of "Austro-Hungarian Bank," and on condition that the Bank be reconstructed in such a form as to satisfy the exigencies of both countries, and to allow the Hungarian Government the same influence in Bank affairs as the Austrian Government. At the same time the so-called 80 million Bank loan affair was settled by stipulating, 
that while the Bank Charter remained in force that part of the Bank's revenue which belongs to the State was to be applied to the repayment of the loan; after the expiration of the Bank Privilege the remaining part of the loan to be repaid by Austria, Hungary contributing to it 30 per cent. of the amount thus remaining, in fifty yearly instalments free of interest. This loan of 80 million florins in bank notes and free of interest was contracted by the then Central Government at the time of the war in 1866.

We now pass on to the present negotiations for the renewal of the agreement, and the actual position of the matter, only taking such items into consideration as now occupy public attention; the agreement itself not being yet arrived at, no details can be given at present.

The Austrians have long alleged that the economic agreement was far more favourable to Hungary than to Austria. First of all, they say, that the Quota burdens Austria more than was right. Hungary, they allege, exercises the same rights with regard to common affairs as Austria, therefore the principle of parity would apply, yet Hungary participates in the burdens only up to 31.4 per cent. But if the Austrians do not insist that Hungary should contribute to the common expenditure in the same proportion as she exereises common rights, that is to say, on the principle of parity, they still insist that it was not just that Hungary should, after the lapse of twenty-five years, still contribute the same amount as in 1867. It is an undisputed fact that Hungary has considerably advanced in wealth during the last twenty-five years, and that increase of wealth ought to find expression in the Quota. They furthermore allege that it was unjust to apply the Custorns Revenue to the common expenditure because Hungary actually participates in that Revenue in the proportion of the Quota, that is 31.4 per cent., whilst the income derived from the Hungarian Custom Houses amounts only to about 18 per cent. of the whole Revenue. Taking the average annual Customs Revenue at 50 million florins, it is evident that Hungary receives about $6 \frac{1}{2}$ millions more than she collects through her Custom Houses.

Again, the Austrians complain that the Hungarians have very skilfully wrested the Customs Treaty to their own advantage and to the detriment of the Austrians. It was even partly alleged that Hungary acted disloyally, often permitting things to be done which were not in harmony with the spirit of the Customs Treaty, such acts being, for instance, the following: levying 
registration duties on goods brought in Austrian rolling stock, whilst within the united Customs territory no dues whatsoever can be levied on goods coming from one part of that territory. In tendering for contracts with the State or municipal authorities, in Hungary, only native goods are admitted, whilst on a united Commercial territory the Austrian goods ought to have the same rights. In Railway policy the principle has been adopted that in the interest of the development of home-industry it was requisite to grant more favourable freight dues to the importation of the raw material and to the exportation of the manufactured articles, hence the handicapping of Austrian manufactures as against the Hungarian. The Hungarian industry is now artificially fostered by exemptions from taxes and by other advantages granted by the State, which also acts detrimentally upon the development of healthy competition within the united territory, and lastly the milling-right conceded to flour mills, that is to say the right of importing foreign grain free of duty on condition of again exporting the flour produced from it, is construed as an extraordinary advantage offered to the Hungarian mills by which they may be enabled to keep up the sale of their flour, even in Austria, against the Bohemian mills.

In Hungary the temper is now much more serene than formerly, and than it was at the time of the various renewals of the agreement. Formerly strong expressions were heard pleading for the total separation of economic interests, also for a separate Customs territory and for an independent Bank. Such were the catch-words and war-cries which now are only used by the party of independence, who adopted the principle of the "Personal Union" as their programme, and who desire it to be applied to every concern. Public opinion demands the abolition of all those regulations which under pretence of veterinary necessity prohibit the importation of Hungarian cattle into Austria, thus closing to the Hungarian cattle-breeder the Austrian markets. There is a general demand that the excise duties on consumption should now be so regulated that the income arising therefrom shall be the property of that State in which the article is consumed. This principle is at present applied only to the spirit duties, whilst the revenue derived from dues levied on sugar, beer, and petroleum, are the property of that state in which they are produced. It is a fact that a large amount of sugar and beer manufactured in Austria and paying the excise duty there to the amount of some two to three million florins is actually consumed in Hungary, and this sum should go into the Hungarian exchequer, 
as being derived from Hungarian consumers. Public opinion in Hungary also demands that by the agreement now to be concluded, the Bank privilege should only be renewed on condition that, with regard to the management of the Bank, Hungary be placed on absolute parity with Austria, and that the present branch office at Budapest shall in every respect have the same rights and power as the chief establishment in Vienna.

The main parts of the agreement have already been settled by the two Governments, and are ready to be laid before the two Legislatures. The two Governments have already on various occasions made some disclosures to their Parliaments, from which it appears that by the new agreement the following items will be regulated: The question of the excise duties will be settled on the principle that the revenue derived therefrom will be the property of that State in which the article is actually consumed; veterinary rules and regulations will be so arranged that free intercourse between the two countries will not be impeded by arbitrary enactments; the railway tariff will likewise be revised in order to remove all causes for complaints about differential treatment of goods sent by the other party; the question of public tenders for contracts is also to be modified to a certain extent so that the industries of both countries may be able freely to participate in the competitions. The Bank question will be settled by the renewal of the Bank Charter on the basis of parity, satisfying the exigencies of Hungary and securing the necessary co-operation of the Bank in the re-establishment of the Currency.

The question of the Quota not being yet finally settled, the two Governments were not yet able to lay the bills relating to the economic agreement before their Legislatures. The Quota must, first of all, be agreed upon by the Commissions nominated for this purpose by the two Parliaments. The two Parliaments have actually nominated their Commissions in 1896, and they have entered into negotiations but have not yet come to an understanding. The course of these negotiations was as follows: On April 14th, 1896, the Austrian Commission sent their proposals to the Hungarian Commission. The pith of the proposal was, that in future the population data should form the basis of calculating the Quota; thus the 30 per cent. paid by Hungary would be increased to 42 per cent., or subtracting first the 2 per cent. in respect of the Frontier Districts, the present total of 31.4 per cent. would be raised to $43 \cdot 16$ per cent. to be paid by Hungary, which amounts to an increase of some 12 millions annually. The 
Austrian Commission considered themselves the more justified in this demand in view of Hungary's great economic development. Moreover, as the total gross expenditure of Austria during the period from 1886 to 1894 averaged 540.6 millions, and Hungary's 389.8 millions, the proportionate part due from Hungary would have been 41.9 per cent. The answer of the Hungarian Commission was that the amount of population could not form the basis for calculating the amount of contribution, because the conditions of wealth of a State and its power to bear burdens cannot be determined by the number of its inhabitants. They quoted Herr Miquel, the German Minister, who declared that the levying, in Germany, of the so-called Matricular-beiträge, according to the amount of population, was radically opposed to economic principles. Bismarck also considered this system as imperfect, and in Switzerland, where in fact the population forms the basis of the contingent contributions, it is rectified according to the varying economic conditions of each Canton. The Hungarian Commission did not consider as well-founded the contention that the amount of the gross revenue justified the application of the principle of population to the calculation of the Quota, because the different nature and form of the two countries' budgets, the difference in the transitory items, the diversity of management and of State property, as also the various taxes introduced into Hungary which do not exist in Austria, render a comparison impossible. Objects differing in nature are thus brought into line for comparison. In the gross revenue the receipts of the railways are included, which Hungary had acquired at the cost of one milliard of florins, and for which she pays annually enormous sums in interest and sinking funds. The increased revenue thus created cannot form the measure of wealth and solvency of a nation.

For these reasons the Hungarian Commission could not accept the proposals of the Austrian Commission, but felt themselves bound to regard the amount of taxation as the only basis for calculation, in the same way as it was regarded in 1887 by the Hungarian Commission. Taking the total revenue derived from direct and indirect taxation, deducting therefrom the onesided taxation, and adding to it, on the Austrian account, the amount derived from the supplementary provincial-tax and the tacitly conceded coupons and lottery taxes, it will be found that the annual (average) revenue from taxation (1886-1894) was, in Hungary, 169.5 millions, and in Austria 434.4 millions; thus resulting in the relation of 28.073 to $71 \cdot 927$. But even if the 
Austrian supplementary provincial-tax, the coupons and lottery taxes are not taken into account, the revenue would still be-in Hungary 169.1, and in Austria 380.6 millions; thus giving the ratio of $30 \cdot 765$ to $69 \cdot 235$. The Hungarian Commission also prepared a series of tables showing conditions of wealth for various groups, and proving that the corresponding relation is everywhere below 30 per cent. Thus, for instance, the Hungarian percentage in the group of persons occupied in industry, mining, and transport is 24.52 ; taking the value of the production of mining and metallurgy it is 24.39 ; membership in industrial benefit societies, 14.88 ; and in contributions to such societies, 12:42. The share capital and reserve funds of the credit institutes give a percentage of $27 \cdot 73$; deposits in postoffice saving banks, 21.03 ; the net' income of railway concerns, $27 \cdot 42$; production of mineral coals, 20.0 . Under such circumstances the Hungarian Commission considers it quite justifiable to keep the present Quota, that is to say, 31.4 per cent.

The exchange of notes has just as little led to an understanding between the two Commissions as the verbal negotiations of the sub-commissions nominated by both parties. Meanwhile regrettable events have taken place in Austria in consequence of the antagonism between the national aspirations of Germans and Czechs (Bohemians), which rendered the Parliamentary labours of the Reichsrath nugatory.

The resettlement of all economic matters concerning common affairs must therefore be postponed and left to the future: Provisionally the status quo remains till 31st December, 1898. The Sovereign has according to law decided to maintain the Quota for the year 1898 at what it has been hitherto. The Hungarian Parliament and the Austrian Government have prolonged for the year 1898 the law relating to all matters of the Ausgleich.

It cannot be denied that the view taken by the Austrians is eminently unjust in representing that by the present state of the economic agreement Hungary has injured Austria, and that therefore they must insist upon a larger amount of contribution. Nobody can deny that Hungary has economically advanced more during the last twenty years than formerly during a century, but neither did progress lag in Austria; for instance, in 1876 there were 12,648 steam boilers with a total of 51,264 atmospheres, and in 1890 these had increased to 20,071 steam boilers with 100,027 atmospheres. Such progress is also noticeable in railways, credit institutes, in the production of pig iron and coal, and in many 
other branches of industry and economy. The wealth of the two States has certainly not developed in such an unequal manner that it would justify the increase of the Hungarian contribution.

In this respect it is sufficient to direct attention to the data on communications, which show that Austria has imported into Hungary goods of the value of 481 millions, against goods imported from Hungary into Austria valued at 390 millions. The entire economy of Hungary has caused great sacrifices to Austrian industry by the protective Customs policy since the Protective Tariff of the years 1872 and 1882, sacrifices which are inadequately compensated for by the advantage of Hungary finding a regular market in Austria for her raw productions.

As it is the interest of both parties to live peaceably together, it may be expected that an agreement will ultimately be reached.

A. Matlekovits 